\title{
ИСПОЛЬЗОВАНИЕ СПЕЦИАЛЬНО РАЗРАБОТАННЫХ И ПРОМЫШЛЕННЫХ ПРОДУКТОВ В ПИТАНИИ КОСМОНАВТОВ ДЛЯ ОПТИМИЗАЦИИ НУТРИОМА ОРГАНИЗМА В УСЛОВИЯХ КОСМИЧЕСКОГО ПОЛЁТА
}

\author{
В. Ф. Добровольский
}

\begin{abstract}
Статья посвящена вопросу питания космонавтов в условиях невесомости и эфрфрективных средств коррекции изменений обмена веществ в этих неблагоприятных условиях. Условия космического полёта, такие как невесомость, ограниченное пространство, неустойчивая радиационная обстановка, искусственная газовая среда, повышенные нервноэмоциональные нагрузки, негативно отражаются на самочувствии космонавтов, сопровождаются определёнными сдвигами в обмене веществ, фуункии пищеварения, состоянии аппетита, снижение внимания и работоспособности. Проведенные исследования ГНЦ ИМБП РАН при участии НИИППиСПТ по изучению изменений, возникающих в организме человека в процессе кратковременных и длительных космических полётов, позволили сфоормулировать теоретические подходы к оптимизации нутриома организма космонавтов путём правильно организованного, адекватного потребностям организма космонавтов питания и на этой основе разработать научно обоснованные подходы к формированию пищевого состава продуктов и рационов питания, ориентированных на использование в условиях пилотируемых космических полётов различной продолжительности. Условия космического полёта предъявляют особые требования как к рациону питания в целом, так и к входящим в его состав продуктам и технологии их изготовления.
\end{abstract}

Ключевые слова: рацион питания, консервы, нутриом организма, сублимационная сушка, сублимированные блюда,

Под космическим питанием подразумеваются продукты, над созданием и обработкой которых трудились лучшие ученые, технологи и инженеры нашей страны. Условия низкой гравитации предъявляют свои требования к этому аспекту, и то, над чем человек на Земле может не задумываться, создает определенные сложности при полете в космосе.

Каждый день человеку на борту космического корабля нужно приблизительно 5,5 кг еды, кислорода и воды. Учитывая, что команда состоит из нескольких человек, и их полет может продолжиться в течение года, необходим существенно новый подход к организации питания космонавтов [1].

На орбите едят практически то же самое, что на родной планете. В меню входит, хлеб Бородинский, сыр, ветчина, мясо с картофрельным пюре, зелёные щи и борщ, свинина в кисло-сладком соусе, судак, осетрина, творог, клубника, печенье, шоколад, чай и кофее. Ещё едят в космосе свежие фрукты и овощи, при этом сохраняются предпочтения национальной кухни.

Американские астронавты заказывают себе цитрусовые (грейпфруты, апельсины и лимоны), а русские предпочитают лук, поми- доры, яблоки, чеснок. Самый любимый продукт всех космонавтов - и наших, и американских - был и остается творог с орехами и с клюквой.

Последний раз в рацион питания космонавтов были включены овсяные каши с персиком и яблоками. Труднее всего в космосе с водой. На космических кораблях осуществляется полная регенерация воды: даже отходы жизнедеятельности очищаются и снова преобразуются в воду.

Основными требованиями к продуктам и рационам питания в космическом полёте являются:

- минимальные габариты и масса;

- длительные сроки годности продукта (не менее 12 мес.);

- удобство приёма пищи в условиях невесомости и её приедаемость в течение длительного времени;

- минимальные затраты времени на приготовление блюд и возможность их использования как в горячем, так и в холодном виде; - хорошая перевариваемость и высокая усвояемость; 


\section{В.Ф. ДОБРОВОЛЬСКИЙ}

- микробиологическая безопасность в течение всего срока хранения в условиях космического объекта.

Для этих целей НИИППиСПТ специально разработаны специальные продукты и рационы питания широкого ассортимента, не требующие особых условий для длительного хранения.

Особые требования предъявляются также к упаковке продуктов. Упаковка должна иметь минимальную массу, обладать достаточным запасом прочности, чтобы сохранять целостность и герметичность продукта при воздействии вибраций, перегрузок, перепадов температуры и давления. В этих условиях упаковка не должна выделять токсических веществ или веществ, обладающих запахом. Кроме того, упаковка должна быть пригодной к использованию в качестве посуды для приготовления и приёма пищи.

Учитывая характер воздействий и вызываемых ими изменений в организме человека, продукты питания космонавтов должны обладать радиопротекторными, антистрессовыми свойствами, повышать устойчивость организма к вестибуловегетативным нарушениям, оказывать профилактический эфрфект на пищеварительную систему и нормализующее влияние на функции жизненно важных систем организма, в том числе сердечнососудистую и иммунную системы [2, 3].

К настоящему времени для питания космонавтов разработано более 300 наименований высококачественных специальных продуктов питания с высокой степенью надёжности и безопасности, имеющих длительные сроки годности в заданных условиях транспортирования и эксплуатации [4].

Кроме того, для обеспечения разнообразия питания космонавтов подобран ассортимент продуктов промышленного производства более 100 наименований, которые могут использоваться в питании космонавтов. Отобранные продукты проверены в контрольных испытаниях на температурные объектовые воздействия, что позволило включить одни продукты в состав дополнительных наборов с ограниченными (не менее 60 суток) сроками годности: икра паюсная из осетровых рыб, аджика, хрен, кетчуп, сырокопчёные мини колбаски и т. д., другие (со сроками годности 12-15 месяцев) - в состав основной части рациона: печёночные паштеты, рыбные, мясные, овощные и фруктовые консервы, йогурты сублимационной сушки, сухие быстрорастворимые напитки, шоколад [5, 6, 7, 8].

Калорийная и богатая белками пища, содержащая белки животного происхождения (мясо, рыба, печень, творог, яйца) и растительные белки (крупяные и бобовые), повышает сопротивляемость организма к вредным фракторам окружающей среды, при этом снижается поступление радионуклидов в организм. Кроме того, белки рыбы, творога, сыра, бобовых содержат серосодержащие аминокислоты (цистин, метионин), которые вызывают самостоятельный радиопротекторный эфрфект.

С учётом этих фракторов в рационе питания экипажей используются:

- первые обеденные блюда с говядиной сублимационной сушки: борщ, щи зелёные, щи из квашеной капусты, рассольник, суп крестьянский, борщ с копчёностями;

- вторые обеденные блюда сублимационной сушки: гуляш, вырезка свиная, поджарка из говядины с гарнирами (капустой, горошком в молочном соусе, картофельным пюре, кашей гречневой), свинина с лечо, рагу овощное с мясом, говядина по-домашнему, изделия макаронные с мясом;

- консервы мясные и из мяса птицы: свинина рубленая с яйцом, телятина с овощами, мясо куриное с яйцом, мясо куриное с черносливом, омлет с куриным мясом, а также подобраны консервы промышленного производства: паштет печёночный «Деликатесный» с зеленью укропа, паштет печёночный «Особый»;

- консервы рыбные: из судака в ассортименте (5 наименований), из лососёвых в ассортименте (5 наименований), белуга натуральная, осётр натуральный, осётр заливной, лещ в остром томатно-горчичном соусе;

Молоко сублимационной сушки, творог с черносмородиновым пюре, с облепиховым пюре, с орехами сублимационной сушки, консервированные плавленые сыры, являющиеся полноценными белковыми продуктами.

Используются такие продукты сублимационной сушки, как суп-пюре гороховый, фасоль по-болгарски, консервы «Фасоль в томатном соусе», содержащие растительный белок.

Для повышения уровня антиоксидантной защиты организма и уменьшения повреждённых клеток при ионизирующем облучении, рекомендуется вводить в РП продукты, содержащие витамины-антиоксиданты: витамин А и его предшественник $\beta$-каротин, C, E.

С этой целью разработаны продукты, содержащие $\beta$-каротин, и определенное количество витамина $\mathrm{C}$ :

- продукты сублимационной сушки: щи зелёные, суп-пюре овощной, гювеч, баклажаны тушеные с картофелем, творог трёх наиме- 


\section{ИСПОЛЬЗОВАНИЕ СПЕЦИАЛЬНО РАЗРАБОТАННЫХ И ПРОМЫШЛЕННЫХ ПРОДУКТОВ В ПИТАНИИ КОСМОНАВТОВ ДЛЯ ОПТИМИЗАЦИИ НУТРИОМА ОРГАНИЗМА В УСЛОВИЯХ КОСМИЧЕСКОГО ПОЛЁТА}

нований, свинина с лечо, каша рисовая с курагой, каша пшеничная молочная с тыквой; соки с мякотью: абрикосовый, персиковочерносмородиновый, яблочно-персиковый, персиково-абрикосовый, сок овощной (томатный с перечным пюре); десерты: «Земляника натуральная», «Малина натуральная»;

- подобраны консервы промышленного производства: паштет печёночный особый, паштет печёночный «Деликатесный» с зеленью укропа.

Также используются продукты, содержащие витамин E: орехи фрундук, миндаль солёный, миндаль сладкий, фруктовоореховые концентраты: чернослив с орехами, яблоки с орехами.

Витамины группы $B: B_{1}, B_{2}, B_{6}, B_{12}$, пантотеновая кислота $\left(B_{5}\right)$, биотин (витамин Н) входят в состав ферментов, участвующих в метаболических процессах в организме. Витамин В 1 способен потенцировать радиопротекторный эфффект других пищевых веществ. Витамины группы восполняются при употреблении таких продуктов, как суп-пюре гороховый, каша пшеничная молочная, каша пшеничная молочная с тыквой, каша рисовая с курагой, каша гречневая с молоком, каша гречневая с грибами, фасоль по-болгарски, фасоль в томатном соусе, грибы постарорусски, паштеты печёночные, консервы мясные и из мяса птицы, первые и вторые обеденные блюда.

Способствуют обогащению рациона применяемые РП витаминные, быстрорастворимые, порошкообразные напитки производства ООО НПК «Фитопродукт»: «Северная вишня» и «Лесная сказка» - натуральные продукты питания повышенной биологической ценности, основой которых являются экстракты дикорастущих трав и плодов, содержащие пектиновые и минеральные вещества (микроэлементы), витамины C, B1, B $\mathrm{B}_{6}$, каротин (A), E, PP, обладающие высокими лечебно-профилактическими свойствами.

Данные напитки рекомендуются людям, находящимся в стрессовых ситуациях, условиях, связанных с физическими и умственными нагрузками, требующих реабилитационных мероприятий для восстановления защитных сил организма.

Напиток «Северная вишня» изготовлен на основе экстрактов плодов шиповника, рябины обыкновенной и черноплодной, черёмухи, листа крапивы, улучшает работу желудочно-кишечного тракта, выводит из организма радионуклиды и токсины, обладает противопростудным и тонизирующим действием.
Напиток «Лесная сказка» изготовлен на основе экстрактов плодов боярышника, черноплодной рябины, травы пустырника, листа мяты, обладает успокаивающим действием, укрепляет сердечно-сосудистую систему, улучшает сон.

Для профилактики возможных неблагоприятных изменений обменных процессов в организме космонавтов необходимо также использовать в рационе продукты, богатые пищевыми волокнами.

Пищевые волокна участвуют в регуляции перистальтики кишечника, стимулируют процессы выделения желчи, обеспечивают нормализацию деятельности полезной микрофрлоры кишечника, адсорбируют экзо- и эндогенные токсины, соли тяжёлых металлов, способствуют выведению радионуклидов из организма.

К продуктам с высоким содержанием пищевых волокон относятся:

- закуски: икра баклажанная, икра кабачковая, икра любительская (из моркови и лука), закуска витаминная (квашеная капуста с морковью и красным перцем), салат из свёклы с луком, фасоль в томатном соусе, солянка овощная из свежей капусты, закуска аппетитная;

- каши;

- первые обеденные блюда: борщ, щи зелёные, щи из квашеной капусты, суп-пюре тыквенно-сырный, суп-пюре овощной, суп-пюре гороховый, суп из шампиньонов;

- вторые обеденные блюда и гарниры: баклажаны тушеные с картофелем, гювеч, фасоль по-болгарски, грибы по-старорусски, каша гречневая, капуста тушёная, горошек в молочном coусе, пюре картофельное;

- кисели с яблочным пектином: клюквенный, яблочно-брусничный, яблочно-вишнёвый;

- десертные блюда: консервированные фрруктомусс из яблок с цельными злаками, брусника дроблёная, пюре из кураги, десерт из яблок, десерт из персиков, компоты из яблок, слив, груш, приправа яблочноклюквенная; сублимированные - «Земляника натуральная», «Малина натуральная», земляника с сахаром, десерт из лесных ягод, десерт из садовых ягод; сублимированные соки с мякотью;

- фруктово-ягодные концентраты: чернослив с орехами, яблоки с орехами, фруктовые палочки из персиков, айвы, яблок и слив, яблок и абрикосов, слив и вишен, чернослив сушёный;

- орехи: фундук, миндаль сладкий, миндаль солёный; 


\section{В.Ф. ДОБРОВОЛЬСКИЙ}

- хлебные изделия: хлеб ржаной московский, хлеб столовый, хлеб бородинский, хлеб пшеничный сдобный, хлеб пшенично-ржаной, коврижка медовая, печенье имбирное, печенье с курагой.

Существенную роль в защитных функциях организма играют минеральные вещества: макроэлементы (кальций, фосфор, калий, натрий, магний, хлор, сера), содержащиеся в пищевых продуктах в относительно больших количествах, и микроэлементы (железо, йод, медь, марганец, цинк, селен, кремний), концентрация которых незначительна. Макроэлементы способны блокировать поступающие в организм радиоактивные вещества.

Кальций является блокировочным элементом радиоактивного стронция, наряду с фосфором это основной компонент костей и зубов. Кроме того, он участвует в поддержании осмотического равновесия внутренней среды организма, активации ряда фрерментов и гормонов.

Для снижения неизбежных в длительной невесомости явлений деминерализации костной ткани у космонавтов необходимо употребление содержащих кальций веществ в продуктах рациона.

По содержанию и полноте усвоения лучшими источниками кальция являются сублимированные продукты: молоко и творог с черносмородиновым пюре, творог с орехами, творог с облепиховым пюре, блюда из бобовых, йогурты, а также орехи, хлебные изделия.

Важным этапом космического полета, требующим коррекции пищевого статуса, является работа вне космического корабля. В организме космонавта повышается уровень энерготрат, происходят определённые сдвиги в составе внутренней среды организма, в частности в обмене веществ. Усиливается потоотделение, приводящее к повышению выделения из организма минеральных элементов, особенно калия и натрия, что служит причиной нарушений водно-солевого обмена. В этом случае рацион питания должен восполнять потери этих элементов.

Содержат калий следующие продукты, включенные в рацион питания: пюре из кураги, чернослив с орехами, чернослив сушёный, яблоки с орехами, палочки фруктовые из яблок и абрикосов, из персиков, из яблок и слив, из слив и вишен, земляника с сахаром, десерты из лесных и садовых ягод, орехи миндаль и фундук, пюре картофельное с грибами, кисели, десерты из яблок, персиков, компоты, все соки сублимационной сушки, приправа яблочно-клюквенная, соус томатно- овощной «Молдова», борщ, суп-пюре гороховый, щи зелёные, суп из шампиньонов, блюда с фасолью, горошек зелёный в молочном coусе, закуска аппетитная, закуска витаминная, консервы рыбные; икра баклажанная, кабачковая, любительская; солянка овощная из свежей капусты, паштеты печёночные, молочные продукты сублимационной сушки.

Для поддержания водно-солевого гемостаза и коррекции энергетического обмена учитывается исключительно важная роль соединений натрия в образовании буферной системы, обеспечивающей кислотнощелочное равновесие в организме.

Соединения натрия (гидрокарбонаты, фосфаты) содержат консервы мясные, из мяса птицы и рыбные, печёночные паштеты, сыры плавленые, суп-пюре гороховый, суппюре тыквенно-сырный, фасоль поболгарски, щи из квашеной капусты, борщ, икра баклажанная, кабачковая, любительская.

Соединения магния, наряду с калием, кроме участия в поддержании постоянства внутренней среды организма, выполняют важную функцию по нормализации деятельности сердечно-сосудистой системы.

Потребность в соединениях магния восполняют следующие продукты: орехи фундук, миндаль сладкий, миндаль солёный, чернослив с орехами, яблоки с орехами, консервы из лососевых рыб, белуга натуральная, осетр заливной, осётр натуральный, каша гречневая с молоком, каша гречневая с грибами.

Микроэлементы важны для стимулирования иммунной системы, обменных процессов, что способствует выводу из организма радионуклидов.

Железо - жизненно важный элемент, участвующий в образовании гемоглобина, помогает вывести токсины и тяжёлые металлы.

Медь, подобно железу, способствует кроветворению, выводит токсины.

Богаты железом и медью блюда сублимационной сушки с мясом, консервы мясные и рыбные, паштеты печёночные, яблоки с орехами, чернослив с орехами, чернослив сушеный, пюре из кураги, каша гречневая с грибами, каша гречневая с молоком.

Йод - блокировочный элемент радиоактивного йода, участвует в функции щитовидной железы, стимулирует работу иммунной системы.

Частично потребность в йоде могут обеспечить сублимированные продукты: суппюре гороховый, борщ, фасоль по-болгарски, каша гречневая с молоком, каша гречневая с

ПОЛЗУНОВСКИЙ ВЕСТНИК № 22018 


\section{ИСПОЛЬЗОВАНИЕ СПЕЦИАЛЬНО РАЗРАБОТАННЫХ И ПРОМЫШЛЕННЫХ ПРОДУКТОВ В ПИТАНИИ КОСМОНАВТОВ ДЛЯ ОПТИМИЗАЦИИ НУТРИОМА ОРГАНИЗМА В УСЛОВИЯХ КОСМИЧЕСКОГО ПОЛЁТА}

грибами, салат из свёклы, консервы: фасоль в томатном соусе, салат из свёклы с луком, консервы из лососёвых.

Марганец способен усиливать действие инсулина, он активно влияет на обмен белков, углеводов и жиров. Цинк входит в состав инсулина и многих важных ферментов.

Содержат марганец и цинк сублимированные продукты: борщ, борщ с копчёностями, суп из шампиньонов, суп-пюре гороховый, творог, салат из свеклы, консервы: рыбные, солянка овощная из свежей капусты, фасоль в томатном соусе, салат из свёклы с луком.

Селен усиливает антиоксидантные свойства витаминов C и E, участвует в синтезе гормонов щитовидной железы.

Потребности в селене могут восполнить рыбные консервы, сублимированные продукты: грибы по-старорусски, картофрель с грибами, гречневая каша с грибами, суп из шампиньонов.

Чай чёрный и чай зелёный способны выводить из организма токсины, соли тяжёлых металлов и укреплять стенки сосудов.

Таким образом, разработанные специальные продукты и применяемые соответствующие продукты промышленного производства, включенные в рационы питания космонавтов по медико-биологическим и техническим требованиям ГНЦ ИМБП РАН, позволяют оптимизировать нутриом организма в неблагоприятных условиях космического полета.

\section{СПИСОК ЛИТЕРАТУРЫ}

1. Научно-теоретические и практические основы обеспечения членов экипажей космических кораблей и станций полноценным питанием / В. В. Добровольский, А. Н. Агуреев, В. В. Поляков, Р. Р. Каспранский. - Москва: типография «АБС Печатный дом», 2007. - 88 с.
2. Разработка и испытания рационов питания экипажей многоразовых космических кораблей / А. Н. Агуреев, В. П. Бычков [и др.] // Авиакосмическая и экологическая медицина. - М. : Изд-во ГНЦ РФ ИМБП РАН, 1994. - № 2. - С. 18-23.

3. Возможности использования специализированных продуктов и биологически активных добавок в повышении адаптационных возможностей организма при воздействии неблагоприятных фракторов космического полета / А. Н. Агуреев [и др.] // Труды Междунар. научн. конф. «Суверенный Казахстан: 15-летний путь развития космической деятельности». - Алматы, 2006. - С. 291-292.

4. Агуреев, А. Н. Гигиеническая оценка рационов питания в экспериментах с длительной изоляцией / А. Н. Агуреев, С. Каландаров, Д. Э. Сегаль // Авиакосмическая и экологическая медицина, 1997. - № 4. - С. 7-11.

5. Физиолого-гигиеническая оценка рационов питания орбитальной станции "Мир” / А. Н. Агуреев [и др.] // Авиакосмическая и экологическая медицина, 1994. - № 5. - С. 8-12.

6. Добровольский, В. Ф. Анализ пищевого статуса членов космических экипажей / В. Ф. Добровольский, А. Н. Агуреев // Вопросы питания, 1999. - № 5-6. - С. 16-19

7. Добровольский, В. Ф. Питание космонавтов: монография / В. Ф. Добровольский. - М.: «Лион Принт», 2000. - С. 155.

8. Агуреев, А. Н. Основные итоги эксплуатации системы обеспечения питанием (СОП) экипажей МКС / А. Н. Агуреев // Москва: Научная книга, 2011. - T. 1. - C. 342-356.

Добровольский Виктор Францевич, главный конструктор по обеспечению экипажей космических объектов отдела космического питания, академик Российской Академии космонавтики им. К.Э. Циолковского, д.т.н., профрессор, заслуженный деятель науки Российской Федерации, дважды лауреат Премии Правительства Российской Федерации в области науки и техники, директор НИИППиСПТ - филиал ФГБУН «ФИЦ питания, биотехнологии и безопасности пищи». 142718, Московская область, Ленинский район, поселок Измайлово, д. 22, тел.: 8 (495) 383-14-92, E-mail:gnuniippspt@gmail.com 